\title{
CAREER MANAGEMENT SKILLS OF STUDENTS IN GENERAL AND VOCATIONAL UPPER-SECONDARY SCHOOLS IN GREECE: CAREER ADAPTABILITY AND SELF-EFFICACY IN CAREER PLANNING
}

\author{
Katerina Argyropoulou \\ University of Athens, Greece \\ E-mail: kargirop@otenet.gr \\ Ioanna Tsikoura \\ European University of Cyprus, Cyprus \\ E-mail: ioannatsikoura1987@gmail.com \\ Andronikos Kaliris \\ University of Athens, Greece \\ E-mail: akaliris@ppp.uoa.gr
}

\begin{abstract}
Contemporary career guidance and counselling approaches with particular interest to subjects which concern the development of career management skills since these skills are considered important means for the active exploration of the vocational course and the development of a career. The development of skills related to career adaptability and self-efficacy in the planning of a career could help students who are finishing Uppersecondary School (Lykeio) to approach creatively their career aims, and to deal effectively with the transitions or unexpected events by applying appropriate actions. The present study employed the survey research strategy in order to examine the level of the career adaptability and self-efficacy in the planning of a career with male and female students $(N=240)$ of Upper-secondary Schools (General Lykeia - GEL) and Vocational Uppersecondary Schools (Vocational Lykeia - EPAL) in Greece. Specifically, it examined the level of skills which students declare that they possess regarding the type of school, their gender and the educational level of the parents. The finding that the levels of career adaptability differentiated not only as regards the gender of the students but also the studies of the father and the mother has presented particular interest while the students who study at the General Lykeia were found to have higher scores in the areas: "career interest" and "curiosity" in the Career Adapt-abilities Scale (CAAS) compared with students who study at the Vocational Lykeia (EPAL). Finally, the motif of the scores in the B'Class of Lykeio showed that the students of EPAL excelled in all the skills apart from the factor "career interest" while correspondingly in the C'class of Lykeio students of the General Lykeio (GEL) excelled in all skill categories.

Keywords: upper-secondary school students, self-efficacy, career adaptability, career management, Perceived Self-Efficacy in Career Planning, Career Adapt-Abilities Scale.
\end{abstract}




\section{Introduction}

In a world of employment that suffers enormous changes within the given environment of a very deep crisis, the development of skills for the life-long management of a career is thought to be a very important resource of every human being's personal and professional life. It concerns those skills which help the individual of every age to collect, analyse, compose and organise information for himself, education and professions, as well as skills in order to take decisions, to effect transfers and to be flexible and adaptable (European Lifelong Guidance Policy Network, 2012). Some of these characteristic skills are readiness for the unexpected; self-efficacy in career planning; career adaptability and resilience (Sidiropoulou-Dimakakou, Besevegis, Argyropoulou, \& Drosos, 2013).

Given that the reality in which we live in is by its nature complex, unsure and changeable it is possible $\tau o$ arise, even in the most carefully planned and strictly controlled circumstances unforeseen unpleasant events and set-backs. The "set-back" is a negatively loaded word which could be replaced with the word "experience". Within this framework, it appears intensely the need for development of skills for career adaptability. In other words, the readiness of the individuals to continuously explore themselves and the environment in order to face up or to accept the change of the working roles in the career and to handle with success all the unexpected transitions in the working area and in the labour market (Savickas, 2013).

Students of the General and the Vocational Lyceums comprise a group with special interest for career guidance and counseling. This population shows some particular characteristics and additional difficulties in their career given that it needs to face up the critical subject of transition from school to university and subsequently to the employment environment. The students knowing well the educational and vocational environment which interests them and in parallel, acquiring the necessary abilities and skills proceed towards effective choices which lead to their development as individuals (Karatzogiannis \& Pantazi, 2014).

The present era characterized by intense complexity and continuous changes in the labour market demands the existence of an educational system and lifelong study which apart from the provision of knowledge would cultivate the abilities and skills of the students. This way, the former will be able to increase their possibilities of finding working places in a difficult economic environment as well as to manage the complex transitions which characterise modern education; training and employment, to investigate the possible opportunities and their personal abilities in order to strengthen their personal sufficiency in their professional life. On the basis of this view in order that students would be able to deal with the large number of their responsibilities and their duties in the new conditions of their personal, educational and professional life, apart from all other abilities and skills they must possess increased skills of adaptability and self-efficacy in their career.

Evidently the directions in the modern labour market are connected with the present economic situation which is prevailing in Greece. The economic and social differentiations that have been established have caused important changes while the socioeconomic difficulty has influenced directly the mental and daily life of the citizens preventing the satisfaction of basic mental and bodily needs which one would expect from his work (Malliarou \& Sarafis, 2012) Under this particular prism, the planning of a career assumes now the dimension of a multisided action which demands the active participation of the individual but also the development of one's ability to manage flexibly and efficiently the labour transitions reducing in this way the influence of outside conditions (Zacher, 2014a). In economically unstable countries the development of skills such as career adaptability promotes optimism and positivity in the way the individuals confront the employment dilemmas and the management of their career (Lechner, Tomasik, \& Silbereisen, 2016), since these skills function and are exploited independently of the conditions not only of place and time but also of personal characteristics.

\section{Career Adaptability}

Career adaptability is a multi-dimensional construct that relates to the variable capacity of individuals to negotiate transitions successfully (Savickas, 2008). It is a conscious and continuous process involving exploration of self and environment, with a widely accepted definition building 
on the original work of Super and Knasel (1981): "the readiness to cope with the predictable tasks of preparing for and participating in the work role and with the unpredictable adjustments prompted by changes in work and working conditions" (Savickas, 1997, p. 254). This definition has been integrated into an international multi-country investigation of career adaptability that has adopted a psycho-social perspective, emphasizing the importance of context by considering the impact of change on social integration (Bimrose \& Hearne, 2012). Referred to as adapt-ability resources, these are regarded as human capital, less fixed than traits, with four dimensions consistently identified as: concern, control, curiosity, and confidence (Savickas, 2013).

\section{Perceived Self-efficacy in Career}

People with high confidence in their abilities tend to face difficult situations as challenges to overcome rather than as threats to be avoided (Bandura, 1997). Therefore, they try to exercise control over various complicated and hard tasks or situations (Kaliris \& Sidiropoulou-Dimakakou, 2012). Perceived self-efficacy in career refers to the beliefs people form in terms of their ability to implement the appropriate actions required to effectively manage various career issues (Sidiropoulou-Dimakakou, Argyropoulou, Drosos, Kaliris, \& Mikedaki, 2015). A relatively high degree of self-efficacy in career may strengthen the ability through which cognitive, social and behavioural skills are organized into a single course of action for the achievement of career objectives. Perceived self-efficacy in career highlights four areas of skills related to career exploration: Career Skills, Career Management, Flexibility at Work and Creativity at Work (Sidiropoulou-Dimakakou, Mylonas, \& Argyropoulou, 2015).

\section{General and Vocational Lykeia in the Greek Educational System}

The General and the Vocational Lykeia are two basic types of school in today's Greek secondary education. They differ on the basis of the employment prospects they provide for their students. Attendance at the General Lykeio lasts for three years. Its aim is the provision of a multisided development of the abilities and the skills of the students and preparation for the assumption of a responsible role within modern society. In the A' Class of the General Lykeio the programme comprises of general education lessons, which are common to all students. In the B' class students are obliged to choose between humanity studies and the positive-technological or health studies in order to acquire a speciality in their future career. In the C' class the orientation groups are divided in (a) humanity studies, (b) positive studies, (c) information technology and economy. Students choose according to their interests the corresponding sciences and the professional activity they wish to pursue and develop. Those possessing a Final Certificate of the Lykeio have the capability to enter the labour market and work on the public or private sector or to enter the Higher Education Institutions or the Higher Technological Education Institutions of the country.

Attendance at the Vocational Lykeia is divided in two cycles. The first cycle is the Secondary Study Cycle and the second one is the Post-Secondary Study Cycle or Apprenticeship Class which the students follow in the C' class of the vocational Lykeio while the study time is divided between the place of work and the school. The apprenticeship is carried out on the basis of a study programme divided between the workplace and the school area and leads to a specific profession (Ministry of Education, Research and Religions, 2016). The General Lykeia are equal with the Vocational Lykeia. Graduates of the Vocational Lykeio are entitled to receive a licence to carry out a profession while they also have access to the tertiary education or to register in the Institutes of Professional Training. In Greece today 212.079 students are registered in the General Lykeia, and 88.713 students are registered in the Vocational Lykeia.

\section{The Importance of Career Guidance and the Development of Career Management Skills in the Secondary Vocational Education}

Although the demand for specialised technicians of middle level qualifications was always very high the vocational training for decades was downgraded in the Greek educational system. Teaching of school vocational orientation is only provided in the A' class of the Vocational Lykeio. Old, deeply 
rooted preconceptions against the so called "manual labour" together with hasty and little convincing reforms in this area sustain this situation unchanged up to the present (Ioannidou \& Stavrou, 2013).

The findings of international comparative research show that the close connection of the vocational training with the demands of the labour market and the economy is an essential precondition for a high quality vocational system which will facilitate the transition from the school to an active life (Cedepof, 2013). The long-term problems of the vocational system of education in Greece particularly under the prism of the dramatic youth unemployment numbers have become so intense that the adoption of radical reforms as soon as possible is an urgent demand. The reform of the vocational education in Greece is programmed at this very moment where study in the school will be divided with learning in a firm with the help of technical and general lessons. Apprenticeship next to professionals does not replace academic knowledge but it promotes as equally important the professional qualifications and the technical skills (Paidousi, 2014)

For this reason, students of vocational education and training must develop skills of career management and to do it within a life-long perspective in order to develop multisided skills and manage better the increasingly more complex and non-linear transitions between education, training and employment. The effectiveness of such activities could be strengthened (a) with the creation of tools which collect, summarize and substantiate different experiences and skills acquired by students during their participation in apprentice programmes; (b) with workshops embodied in the weekly lesson (training for the development of social and personal skills, skills for job search and skills which employers are searching); and (c) with the use of electronic systems of career guidance and access to the internet where skills relating to entrepreneurial and career adaptation are cultivated (Nathan \& Hill, 2006; Sidiropoulou-Dimakakou, Argyropoulou, \& Drosos, 2013).

Based on the importance for the development of career management skills of upper-secondary education students whatever the type of school, a quantitative research was designed to examine career adaptability and self-efficacy in career planning of Greek students who attend General Lykeia (GEL) and Vocational Lykeia (EPAL). The particular objective of the study was to investigate the fundamental factors - dimensions which comprise the career adaptability and the self-efficacy in the planning of careers of the Greek students under the influence of the demographic variables (gender, age, parents' educational level and type of school attended). Moreover, as long as the career adaptability is connected with the beliefs of personal efficacy of the individual, it was thought interesting to examine if there is a relation of the career adaptability with self-efficacy in career planning of the Greek students. The findings of this survey are interpreted in the framework of career guidance and counselling and methods of exploiting them by the career counsellors are proposed. The strengthening of career adaptability of Greek students as well as the self-efficacy in career planning is possible to contribute towards positive actions for themselves and for exploiting as much as possible their potential.

\section{Methodology of Research}

The data collection took place from September to November 2016. A cross-sectional survey design was employed in the research. A survey design is appropriate for researchers to provide a numeric description of trends, attitudes or opinions of a population by studying a sample of that population. The purpose of this type of study is to generalize from a sample to a population so that inferences can be made about a characteristic, attitude or behaviour of this population. This constitutes the major advantage of a survey research design (Creswell, 2009, p. 145-146).

Specifically, the main research questions of the survey were as follows:

1. Is there a correlation between the dimensions (sub-scales) of career adaptability and the dimensions (sub-scales) of the self-efficacy in career planning in the entire sample?

2. Is there a difference in the levels of career adaptability between the students of the General Lykaia and the students of the Vocational Lykeia?

3. Is there a difference in the levels of self-efficacy in career planning between the students of the General Lykeia and the students of the Vocational Lykeia? 
4. Is there a difference in the grading of career adaptability taking into consideration the gender of the students and the educational level of the parents?

5. How is the grading of self-efficacy in career planning differentiated taking into consideration the gender of the students and the educational level of the parents?

6. Is there a difference in career adaptability levels between the students who attend the same classes of the General Lykeia and those students who attend the corresponding classes of the Vocational Lykeia?

7. Is there a difference in self-efficacy in career planning levels between students who attend the same classes of the General Lykeia and those students who attend the corresponding classes of the Vocational Lykeia?

Sample

The sample of the present survey consisted of 240 students of which 120 attended General Lykeio and 120 attended a Vocational Lykeio. From the students of the General Lykeio 50 (41.7\%) were males and $70(58.3 \%)$ were females. The age of the participating students ranged from 15 to 18 with an average age of 16.6 years and a standard deviation of 3.5. The Vocational Lykeio students were $96(80 \%)$ males and $24(20.0 \%)$ females. The age of the students ranged from 15 to 19 with an average age 16.9 years and a standard deviation of 0.8 . Students from all classes of both the General Lykeio and the Vocational Lykeio participated in the survey.

\section{Procedure}

The questionnaires were made available in the teaching area of the sample. The participants completed the questionnaires during their presence in the lesson, before the start of the lesson and during the breaks. Participation in the study was voluntary. No award was given for participating in this research. Confidentiality of the data was maintained throughout all research stages.

\section{Instruments}

The following questionnaires were used to collect data.

Career adaptability. The adjusted Greek form (Sidiropoulou-Dimakakou, Mikedaki, Argyropoulou, \& Kaliris, submitted for publication) of the Career Adapt-abilities Scale - International Form 2.0 (CA-AS; Savickas \& Porfeli, 2012) was used to indicate the level of participants in career adaptability resources. The Greek scale consists of 24 items, the same as the original one. Participants responded to each item employing a 5-point Likert-type scale ( $1=$ not strong, 5=strongest). Below, examples of items are given for each sub-scale: Concern: "thinking about what my future will be like", control: "taking responsibility for my actions", curiosity: "Becoming curious about new opportunities", confidence: "Performing tasks efficiently". High reliability is reported as to the total scale (.92) and the sub-scale scores [concern (.83), control (.74), curiosity (.79) and confidence (.85)]. In the current study $\alpha$ estimates were also high (concern: .90, control: .89, curiosity: .93, confidence: .93).

Perceived self-efficacy in career. Perceived Self-efficacy in Career Scale (PSECS; SidiropoulouDimakakou, Mylonas, \& Argyropoulou, 2012) was used to explore career self-efficacy beliefs. The 21 -item scale has reached adequate psychometric properties in studies with adults $(N=126)$ and high school students $(N=276)$. Four dimensions were supported by exploratory and confirmatory factor analyses (Sidiropoulou-Dimakakou, Mylonas, et al., 2015): Career management represents individual's ability to cope effectively with practical and emotional issues in career (e.g. "I believe I am able to achieve most of the career goals that I have set for myself despite the current social and economic difficulties"); Career skills relates to the utilization of organizational skills and performance when working under harsh conditions (e.g. "In general, I can think of alternative ways to better organize my work and become more efficient"); Flexibility at work refers to a person's ability to adapt to 
transitions and changes that may occur in the workplace (e.g. "Even when duties in my job change, I am able to perform efficiently"); Creativity at work represents active interest in career through creativity and ingenuity (e.g. "Thanks to my resourcefulness, I know how to deal with unexpected situations in my work"). Items are scored on a 5-point Likert-type scale ( 1 = no confidence at all, $5=$ complete confidence). Alpha estimates in this sample were high for the sub-scales $(.89, .92, .87, .90)$.

Demographics Questionnaire. An improvised questionnaire for the collection of demographic data was created, which included questions about gender, age, place of residence, school, study class, direction or study major, participation in a career guidance program, the educational level of parents and their profession.

\section{Data Analysis}

Each questionnaire was screened by the first author in order to guarantee that no missing data occurred. As a result, there were only few missing data which were substituted by the mean score of the item (Graham, 2009). Descriptive statistics (mean and standard deviation) and internal consistency estimates (Cronbach's $\alpha$ ) for the scores of the students at the scales and the sub-scales of the survey were calculated. Comparisons between the scores of the scales and the sub-scales between males and females were made with the help of Mann-Whitney $U$ criterion, while the univariate and the multivariate comparisons of the scores of self-efficacy in career planning and career adaptability dimensions as to the demographic variables (parents' educational level, type of school etc.) were made employing either one-way analysis of variance (ANOVA) or multivariate analysis of variance (MANOVA), respectively. Correlations among the dimensions of career adaptability and self-efficacy in career were computed by making use of Spearman $r$ correlation coefficient.

\section{Results of Research}

\section{Psychometric Characteristics of the Scales}

The internal consistency indices for the four factors separately of the Career Adapt-abilities Scale (Savickas \& Porfeli, 2012) and for the four factors of the Perceived Self-Efficacy in Career Scale (Sidiropoulou-Dimakakou, Mylonas, et al.,2015) correspondingly were assessed. For the analyses the theoretical factorial structure of the two scales was followed. All reliability indices were satisfactory ranging from 0.89 to .93 .

Table 1. Cronbach's a indices of the subscales used in the survey.

\begin{tabular}{lcc}
\hline Career adaptability & Cronbach's $\boldsymbol{\alpha}$ & Number of items \\
\hline Concern & .908 & 6 \\
Control & .899 & 6 \\
Curiosity & .927 & 6 \\
Confidence & .934 & 6 \\
\hline Perceived self-efficacy in career & & 5 \\
\hline Career management & .893 & 7 \\
Career skills & .915 & 4 \\
Flexibility at work & .877 & 5 \\
\hline
\end{tabular}


For the needs of the analyses the average answers of the participants were calculated in the factors in which the scales of self-efficacy in career planning and career adaptability are compounded. The possible width of the values for all the 8 factors of the scales was from 1 to 5 . Table 2 shows descriptive statistical indices for these 8 factors. According to these results it could be surmised that the participants showed moderate scores (around 3) in all the career adaptability and self-efficacy in career dimensions. This suggests moderate ability regarding the efficient confrontation of career issues but also the feeling of adaptation on career issues.

Table 2. Means and standard deviations of the CAAS and Perceived Self-Efficacy in Career subscales.

\begin{tabular}{lll}
\hline & $\boldsymbol{M}$ & $\boldsymbol{S D}$ \\
\hline Concern & 3.23 & .96 \\
Control & 3.25 & .95 \\
Curiosity & 3.16 & .99 \\
Confidence & 3.30 & .99 \\
Career management & 3.03 & .83 \\
Career skills & 3.14 & .83 \\
Flexibility at work & 3.17 & .87 \\
Creativity at work & 3.16 & .85 \\
\hline
\end{tabular}

The Influence of the Demographics in the Career Adapt-abilities Scale and in the Perceived Self-Efficacy in Career Scale

Initially the influence of the gender in the career adaptability and the self-efficacy in career was examined. More specifically the difference between males and females was examined as regards the values of the four factors of the career adaptability and the four factors of the self-efficacy in career. The Mann-Whitney $U$ criterion was used to meet this purpose. The results of the analysis are presented in Table 3. Statistically an important difference was found between boys and girls regarding the interest for the career and the curiosity. More specifically the females displayed a higher level of interest for their career and they had an increased curiosity for their career in relation to the males.

Table 3. Examination of differences in Career Adapt-abilities Scale and Perceived Self-Efficacy in Career Scale based on students' gender.

\begin{tabular}{lcccccc}
\hline & \multicolumn{7}{c}{ Gender } \\
\cline { 2 - 7 } & \multicolumn{7}{c}{ Males } & \multicolumn{2}{c}{ Females } & \\
\cline { 2 - 7 } & $\boldsymbol{M}$ & SD & $\boldsymbol{M}$ & SD & $\boldsymbol{U}$ & $\boldsymbol{p}$ \\
\hline Concern & 3.10 & 1.01 & 3.44 & .85 & 5386.500 & .005 \\
Control & 3.19 & 1.04 & 3.35 & .80 & 6424.500 & .400 \\
Curiosity & 3.06 & 1.07 & 3.32 & .85 & 5756.500 & .034 \\
Confidence & 3.24 & 1.09 & 3.40 & 83 & 6371.000 & .392 \\
Career management & 2.99 & .90 & 3.11 & .72 & 6286.000 & .265 \\
Career skills & 3.09 & .91 & 3.24 & 70 & 6035.500 & .132 \\
Flexibility at work & 3.15 & .94 & 3.22 & .75 & 6513.000 & .557 \\
Creativity at work & 3.14 & .92 & 3.20 & .75 & 6687.500 & .805 \\
\hline
\end{tabular}


Subsequently, our interest turned in the examination of the influence that might have the type of Lykeio in the grading of the career adaptability and the self-efficacy in career planning in the students' sample. More specifically the difference in the scores of the aforementioned scales between those students who attended General Lykeia and those students who attended Vocational Lykeia was examined. The results of the analysis are presented in Table 4. The statistical criterion Mann-Whitney $U$ was used for this purpose. Statistically significant differences between those students who attend Vocational Lykeio (EPAL) and those students who attend General Lykeio (GEL) regarding interest for the career, curiosity, career management, career skills, flexibility at work and the creativity at work were found. All these differences were recorded in favour of the GEL students.

Table 4. Differences in career adaptability and perceived self-efficacy in career planning dimensions based on the school type.

\begin{tabular}{lcccccc}
\hline \multicolumn{7}{c}{ School Type } \\
& \multicolumn{7}{c}{$\begin{array}{l}\text { Vocational Upper- } \\
\text { secondary School }\end{array}$} & $\begin{array}{l}\text { General Upper- } \\
\text { secondary School }\end{array}$ & & \\
\hline & $\boldsymbol{M}$ & SD & $\boldsymbol{M}$ & $\boldsymbol{S D}$ & $\boldsymbol{U}$ & $\boldsymbol{p}$ \\
\hline Concern & 2.94 & 1.02 & 3.53 & .82 & 4743.500 & .0001 \\
Control & 3.13 & 1.06 & 3.37 & .82 & 6481.500 & .177 \\
Curiosity & 2.97 & 1.03 & 3.36 & .92 & 5650.000 & .004 \\
Confidence & 3.17 & 1.09 & 3.44 & .88 & 6350.500 & .137 \\
Career management & 2.83 & .88 & 3.24 & .73 & 5488.500 & .001 \\
Career skills & 2.97 & .88 & 3.33 & .75 & 5579.500 & .003 \\
Flexibility at work & 2.96 & .89 & 3.39 & .80 & 5374.000 & .001 \\
Creativity at work & 2.99 & .89 & 3.33 & .79 & 5825.000 & .013 \\
\hline
\end{tabular}

The Influence of the Educational Level of the Father in the Career Adaptability and the Perceived Self-efficacy in Career Planning

Additionally, the influence of the educational level of the parents (father) in the scores of the career adaptability and the self-efficacy in career planning was examined. The results of the analysis are presented in Table 5. A One-Way ANOVA was used for this purpose. Where important statistical differences appeared the Bonferroni post-hoc criterion was employed. Regarding the educational level of the father, statistically significant differences appeared at all scales. More specifically from the post-hoc criterion it appeared that students whose fathers had received university education recorded a higher "career interest", "curiosity" and "career management" in relation to students whose fathers had finished either Primary or Secondary Education, or a Higher Institution. Also, for the "career management" factor it appeared that students whose fathers had finished a Higher Institution showed a better management in comparison with the students whose parents had only completed Primary Education. Moreover, students whose fathers had completed university education exhibited higher "confidence", "career skills", "flexibility" and "creativity" at work in relation to the students whose fathers had completed an educational level of Gymnasium/Lykeio. Finally, students whose fathers had university education exhibited higher scores in the "control" subscale in comparison with students whose fathers had finished higher institution. 
Table 5. Differences at the scores of career adaptability and perceived selfefficacy in career dimensions based on father's educational level.

Father's educational level

\begin{tabular}{|c|c|c|c|c|c|c|c|c|c|c|}
\hline & \multicolumn{2}{|c|}{ Primary School } & \multicolumn{2}{|c|}{ High School } & \multicolumn{2}{|c|}{$\begin{array}{l}\text { Higher Level } \\
\text { Education }\end{array}$} & \multicolumn{2}{|c|}{$\begin{array}{l}\text { University } \\
\text { Degree }\end{array}$} & \multirow[b]{2}{*}{$F$} & \multirow[b]{2}{*}{$p$} \\
\hline & M & SD & M & SD & M & SD & M & SD & & \\
\hline Concern & 2.31 & 1.00 & 3.01 & .99 & 3.18 & .85 & 3.61 & .89 & 8.754 & .001 \\
\hline Control & 2.69 & 1.22 & 3.15 & 1.01 & 3.11 & .86 & 3.52 & .85 & 4.100 & .007 \\
\hline Curiosity & 2.15 & .87 & 2.97 & 1.01 & 3.07 & .93 & 3.53 & .92 & 8.351 & .001 \\
\hline Confidence & 2.96 & 1.41 & 3.13 & 1.03 & 3.25 & .93 & 3.55 & .90 & 2.965 & .033 \\
\hline $\begin{array}{l}\text { Career } \\
\text { management }\end{array}$ & 2.13 & 1.32 & 2.86 & .85 & 3.04 & .71 & 3.29 & .78 & 7.337 & .001 \\
\hline Career Skills & 2.70 & 1.51 & 2.99 & .86 & 3.10 & .75 & 3.39 & .75 & 4.227 & .006 \\
\hline Flexibility at work & 2.63 & 1.68 & 2.99 & .81 & 3.17 & .77 & 3.44 & .84 & 5.073 & .002 \\
\hline Creativity at work & 2.63 & 1.53 & 3.02 & .85 & 3.13 & .77 & 3.40 & .82 & 3.865 & .010 \\
\hline
\end{tabular}

The Influence of the Educational Level of Parents (Mother) in the Career Adaptability and the Self-efficacy in Career Planning

Moreover, the influence of the educational level of the parents (Mother) in the career adaptability and the self-efficacy in career planning was examined. The results of the analysis are presented in Table 6. For this purpose, a one-way ANOVA was used. Where important differences occurred the Bonferroni post-hoc criterion was employed. In regard to the educational level of the mother, statistically significant differences were found in all levels except that of "confidence". More specifically students whose mothers had university education recorded higher "interest" in career and increased scores in the "career management" factor in comparison with students whose mothers had primary or secondary education.

Table 6. Differences at the scores of career adaptability and perceived selfefficacy in career dimensions based on mother's educational level.

\begin{tabular}{|c|c|c|c|c|c|c|c|c|c|c|}
\hline \multicolumn{11}{|c|}{ Mother's educational level } \\
\hline & \multicolumn{2}{|c|}{ Primary School } & \multicolumn{2}{|c|}{ High School } & \multicolumn{2}{|c|}{$\begin{array}{l}\text { Higher Level } \\
\text { Education }\end{array}$} & \multicolumn{2}{|c|}{$\begin{array}{l}\text { University } \\
\text { Degree }\end{array}$} & \multirow[b]{2}{*}{$F$} & \multirow[b]{2}{*}{$p$} \\
\hline & $M$ & $S D$ & $M$ & $S D$ & $M$ & $S D$ & $M$ & $S D$ & & \\
\hline Concern & 2.26 & 1.16 & 3.05 & .99 & 3.17 & .88 & 3.56 & .88 & 7.412 & .001 \\
\hline Control & 3.05 & 1.34 & 3.20 & 1.03 & 3.12 & .89 & 3.40 & .86 & 1.324 & .267 \\
\hline Curiosity & 2.70 & 1.49 & 3.01 & .97 & 3.15 & .99 & 3.40 & .93 & 2.960 & .033 \\
\hline Confidence & 3.17 & 1.67 & 3.26 & 1.00 & 3.27 & 1.05 & 3.40 & .90 & .399 & .754 \\
\hline Career management & 2.29 & 1.27 & 2.92 & .86 & 2.93 & .74 & 3.29 & .74 & 6.002 & .001 \\
\hline Career skills & 2.78 & 1.57 & 3.06 & .87 & 3.03 & .74 & 3.33 & .74 & 2.692 & .047 \\
\hline Flexibility at work & 2.79 & 1.72 & 3.06 & .86 & 3.07 & .80 & 3.39 & .79 & 3.203 & .024 \\
\hline Creativity at work & 2.51 & 1.47 & 3.11 & .83 & 3.05 & .84 & 3.35 & .79 & 3.363 & .019 \\
\hline
\end{tabular}


Another research question pertained to the influence of the class and the type of Lykeio in the career adaptability and the self-efficacy in career planning. More specifically the difference in the scores of career adaptability and career self-efficacy was examined between students of General Lykeia and students of Vocational Lykeia. The results of this analysis appear in the Table 7. The multivariable criterion MANOVA was used. In the B' class of Lykeio the pattern of the scores showed that the EPAL students are superior in all the skills. In the A' class they were superior only in "confidence" and "interest". In the C' class of Lykeio however, General Lykeia students are superior in all skill categories.

Table 7. Differences at the scores of career adaptability and perceived selfefficacy in career dimensions based on class and type of Uppersecondary School.

\begin{tabular}{|c|c|c|c|c|c|c|c|c|c|c|c|c|}
\hline & \multicolumn{12}{|c|}{ School Type } \\
\hline & \multicolumn{6}{|c|}{ Vocational High School } & \multicolumn{6}{|c|}{ General High School } \\
\hline & \multicolumn{6}{|c|}{ Class } & \multicolumn{6}{|c|}{ Class } \\
\hline & \multicolumn{2}{|c|}{$A^{\prime}$} & \multicolumn{2}{|c|}{ B' $^{\prime}$} & \multicolumn{2}{|c|}{$\mathrm{C}^{\prime}$} & \multicolumn{2}{|c|}{$A^{\prime}$} & \multicolumn{2}{|c|}{ B' $^{\prime}$} & \multicolumn{2}{|c|}{$C^{\prime}$} \\
\hline & $M$ & $S D$ & $M$ & $S D$ & $M$ & $S D$ & $M$ & $S D$ & $M$ & $S D$ & $M$ & $S D$ \\
\hline Concern & 3.75 & .59 & 3.05 & 1.07 & 2.87 & .98 & 3.63 & .87 & 3.24 & .71 & 3.46 & .77 \\
\hline Control & 3.42 & .59 & 3.34 & 1.11 & 2.98 & 1.02 & 3.51 & .93 & 3.05 & .68 & 3.28 & .69 \\
\hline Curiosity & 3.17 & .94 & 3.16 & 1.10 & 2.84 & 1.00 & 3.59 & 1.02 & 2.81 & .76 & 3.22 & .73 \\
\hline Confidence & 3.92 & 1.06 & 3.31 & 1.11 & 3.04 & 1.08 & 3.64 & .97 & 3.12 & .48 & 3.27 & .80 \\
\hline $\begin{array}{l}\text { Career } \\
\text { management }\end{array}$ & 2.90 & 1.27 & 3.04 & .98 & 2.70 & .80 & 3.41 & .80 & 2.81 & .68 & 3.14 & .59 \\
\hline Career skills & 3.29 & .61 & 3.20 & .97 & 2.82 & .82 & 3.51 & .82 & 2.92 & .60 & 3.22 & .63 \\
\hline Flexibility at work & 3.38 & .88 & 3.24 & .98 & 2.79 & .80 & 3.56 & .86 & 3.08 & .79 & 3.27 & .69 \\
\hline Creativity at work & 3.10 & .99 & 3.29 & 1.00 & 2.81 & .79 & 3.51 & .87 & 2.96 & .57 & 3.20 & .68 \\
\hline
\end{tabular}

Correlations between Career Adaptability and Self-efficacy in Career Planning

The correlations between the dimensions of career adaptability and those of self-efficacy in career were computed. For this purpose, the Spearman's rho coefficient was used. Statistically significant positive correlations were observed between the four sub-scales of the career adaptability and the sub-scales of the self-efficacy. This result potentially shows that the more adequate students feel regarding the management of important career issues, the more they feel they can adapt to changes and transitions regarding their career development, through the exhibition of abilities such as interest for career, curiosity, control and confidence.

Table 8. Correlations between the dimensions of career adaptability and selfefficacy in career.

\begin{tabular}{|c|c|c|c|c|}
\hline Spearman'srho & Career management & Career skills & $\begin{array}{l}\text { Flexibility at } \\
\text { work }\end{array}$ & Creativity at work \\
\hline Concern & $.492^{* *}$ & $.495^{\prime \prime}$ & $.476^{\prime \prime}$ & $.487^{\prime \prime}$ \\
\hline Control & $.602^{*+}$ & $.651^{*}$ & $.635^{* *}$ & $.627^{* \prime}$ \\
\hline Curiosity & $.583^{* *}$ & $.611^{* *}$ & $.564^{* *}$ & $.586^{* \prime}$ \\
\hline Confidence & $.595^{* *}$ & $.666^{*}$ & $.585^{* *}$ & $.610^{* \prime}$ \\
\hline
\end{tabular}


The basic aim of this survey was to examine career adaptability and self-efficacy in career of the students who attend General Lykeia and Vocational Lukeia in Greece, because this age group is approaching its entrance to higher education institutions or/and the labour market. In the present research we examined also the relationship between the dimensions of the previous scales that refer to specific crucial skills of career development as well as to what degree the scores are differentiated in the dimensions of these scales under the influence of demographic variables (gender, parents' educational levels, class and type of Lykeio attended).

The relationship between the career adaptability and the self-efficacy in career planning was found to be positive, a finding that shows particular importance, since it shows that the readiness of the individual to confront the unexpected adjustments and transitions of his/her career course is related with the feeling of his/her own efficacy for career issues. These results agree with recent research findings in Greece and Cyprus (Joud, 2016. Sidiropoulou-Dimakakou et al., 2015) while they are also related to the findings of other relative international surveys which show that career adaptability is connected with a feeling of personal control and the opportunities of personal development (Duffy, 2010; Mikedaki, 2015; Rottinghaus, Buelow, Matyja, \& Schneider, 2012). It would appear then that when the individual possesses high career adaptability, may also exhibit high-level skills which help him/her to confront effectively the career issues as well as to organise relevant actions in such a way that could deal successfully throughout the career course. As a result, this finding strengthens the perception connected to the contemporary need for self-management of the career due to the current socio-economic variability, through the development of a nexus of skills in regard to career planning and exploration.

As to the Career Adapt-abilities Scale, students achieved higher scores among the four factors in "confidence" and "curiosity" while for the Perceived Self-Efficacy in Career Scale, students achieved higher scores in the factor "flexibility at work". Given the crisis and the difficulty of finding employment, this finding possibly shows that the students of the sample are trying to develop confidence in their strengths and their ability to examine their career in order to formulate in an effective way their future and to enter the labour market (Vergas, 2016).

According to the demographic variable it was interesting that the girls showed a higher level of "interest" for their career as well as increased "curiosity" for their career in comparison with the boys. This finding possibly establishes the impression that the girls mature faster than the boys (Cole $\&$ Cole, 2002) and as a result they are oriented towards the future examining the various opportunities that are offered by the environment (Sidiropoulou-Dimakakou \& Drosos, 2008).

Moreover, it was found that students in the C' class of the GEL excelled in comparison with the students of the EPAL in the factors of career adaptability (career interest, curiosity, control, selfconfidence) as well as in the factors of the career self-efficacy (career management, career skills, work flexibility and creativity). This finding perhaps is due to the fact that in the period close to the Panhellenic Entrance Examinations in Higher Education the students of the GEL appear to be more conscious of their future studies and professional direction. It would appear that they place higher and long-term targets and a desire to succeed. This perhaps leads them to participate more energetically in relation to the EPAL students in the corresponding class with subjects of career that are of interest to them showing higher interest and curiosity for the discovery of future educational and occupational opportunities, cultivating the feeling of a personal control and self-confidence for their targets while in parallel they acquire a feeling of adequacy for the management of subjects of career and develop skills for planning a career. The choice of their educational direction, or future studies is done consciously. It is possible that at the same time GEL students decide on alternative study choices apart from the first choice.

On the other hand, it was found that the students of the EPAL in the B' class of Lykeio excelled in all the skills apart from the "career interest". This finding possibly shows the intense interest which the students in the GEL develop, already from the B' class in relation with the future educational and occupational opportunities and the decisions for a career they are asked to take. Students in the area of vocational training are often found there not by choice but because they have been led by the general educational system, or because they did not have any better choices (Sidiropoulou- 
18 Dimakakou, Argyropoulou, Drosos, \& Terzaki, 2012). However, in the present survey the relative high level exhibited by the EPAL students, particularly in the A' and B' class of Lykeio, in the various factors of career adaptability (i.e. the scores on factor "confidence" in the A' class of EPAL was 3.92) and career self-efficacy possibly reflects the increased self-confidence of these students regarding the control and the planning of their professional life, a feeling which could be attributed to the immediate association of the study programme of the EPAL with the labour market and the practice of a specific occupation. In parallel the facts above provide a stimulus for a deeper future research in respect with the levels of self-efficacy and career adaptability of the EPAL students in relation to the stage of their training.

In addition, the effect of the educational level of the father in the career adaptability and the self-efficacy in career planning was examined. From the analysis it was revealed that the students whose fathers were graduates of university showed higher scores in the dimensions of "career interest", "curiosity" and the "career management" in comparison with those students whose fathers had a primary, secondary, or post-secondary education. At the same time the influence of the educational level of the mother in the scores at each sub-scale used in the survey was also investigated. Significant differences were found for all the sub-scales. More specifically it was found that students whose mothers had received university education showed significantly higher scores in all the skills in comparison with students whose mothers had received primary or secondary education or had graduated from a post-secondary institute. These findings lead us to the conclusion that the educational level of the parents differentiates the career adaptability and the self-efficacy in career planning in the students of the sample. As a result, it is shown by the specific results that the career development process involves an interactive process between the individual and its environment (Joud, 2016) while the development of the feeling of a personal adequacy in the career is not due only to sources of self-regulation but also an important role is played by other social and environmental factors such as the family (Lechner et al., 2016).

Finally, statistically important differences in the variables of the study in relation to the school class did not arise. In any case, what became extremely obvious from the present survey is that not only the career adaptability but also the self-efficacy in career planning are thought to be important and essential skills for the students, necessary for their ability to manage in an effective way their career and respond successfully in an increasingly complex and fluid labour market.

\section{Limitations}

As the specific sample was numerically relatively small $(N=240)$ and the students were only from the North of Greece, there exists the need for a further study of the same subject. In parallel the need for further research on different types of student population, different types of school, examining factors such as the socio-economic substructure, the age of the students, the role of the teachers and the content of the services of career guidance and counseling in the development of skills provided. Moreover, although career adaptability constitutes in our time, the basic axis of research interest in the area of career guidance and counseling this research has not focused sufficiently in specific groups, such as the culturally different students. In the context of Greece, which is going through a particular combination of economic, social and cultural transitions it would have special interest the continuation of research towards this direction.

Another restriction of this survey which would be possible to be dealt with in the future was that the factors of the career adaptability and the career self-efficacy were not examined longitudinally as a result of which to be unable to support the existence of a causative relationship between the variables.

\section{Conclusions}

The results of the current research effort have led us to some very useful conclusions which add new knowledge regarding the very important role of the career adaptability and the self-efficacy in career planning in the students' career design. Given the data of the study we need to emphasize that it is necessary within the framework of the Greek educational system, the upgrading of the career guidance services in the school environment, the release of the lesson from the daily school 
programme and the provision of career guidance services in the school area, with the appropriate infrastructure, equipment and staffing, since as a result of the political decisions in the last few years, these services within the school have been completely neglected. Activities such as visits in workplaces and the development of mobility programmes in secondary education would encourage the cultivation and the exploitation of the students' career management skills. Moreover, the provision of career guidance and counselling to the parents of the students would appear to be necessary so that the intense influence of certain stereotypical views of the parents for the professional choices of the students should be curtailed.

Another important subject is pertained to the training of career counsellors, who it is necessary to train more systematically in career guidance and counselling through specialised training programmes so that they are able to co-ordinate their activities such as seminars and workshops for the development of skills for career management of the students, to provide the appropriate educational and vocational information, exploit correctly the modern and traditional electronic tools of career assessment (questionnaires, tests, and other qualitative methods), help the students to connect theoretical knowledge with practice etc. The training of career counsellors should not be restricted to one basic familiarization of the object but should be a continuous life-long objective.

\section{Reference}

Bandura, A. (1997). Self-Efficacy: The exercise of control. USA: Freeman \& Company.

Bimrose, J., \& Hearne, L. (2012). Resilience and career adaptability: Qualitative studies of adult career counselling. Journal of Vocational Behavior, 81 (3), 338-344. doi:10.1016/j.jvb.2012.08.002.

European Lifelong Guidance Policy Network (2012). European Lifelong Guidance Policies: Progress Report 2011-2012. A Report on the Work of the European Lifelong Guidance Policy Network 2011-2012.

Cedepof. (2013). On the way to 2020: Data for vocational education and training policies-indicator overviews. Luxemburg.

Cole, M., \& Cole, S. (2002). E anaptiksi ton pedion: Efevia [The development of children: Adolescence]. Athens: Typothito.

Creswell, J. W. (2009). Research design: Qualitative, quantitative, and mixed methods approaches (3rd ed.). Thousand Oaks, CA: Sage.

Duffy, R. D. (2010). Sense of control and career adaptability among undergraduate students. Journal of Career Assessment, 18 (4), 420-430.

European Lifelong Guidance Policy Network. (2012). ELGPN Tool No. 1. Lifelong Guidance Policy Development: A European resource kit. Available at: http://www.elgpn.eu/publications/elgpn-tools-no1-resource-kit.

Graham, J. W. (2009). Missing data analysis: Making it work in the real world. Annual Review of Psychology, $60,549-576$.

Joud, T. (2016). Epaggelmatiki prosarmostikotita ke aftoapotelesmatikotita sto sxediasmo stadiodromias kata ti metavasi ton Kiprion fititon apo to panepistimio stin agora ergasias [Career adaptability and self-efficacy in career planning during the transition of Cypriot students from university to the labor market] (Unpublished MA thesis). European University of Cyprus.

Ioannidou, A., \& Stavrou, S. (2013). Reformperspektiven der Berufsbildung in Griechenland. Internationale Politikanalyse [Reform perspectives of VET in Greece. International policy analysis]. Berlin: Friedrich Ebert Foundation. Retrieved from http://library.fes.de/pdf-files/id/10314.pdf.

Kaliris, A., \& Sidiropoulou-Dimakakou, D. (2012, November). Pepoithiseis aftoapotelesmatikotitas ke ekseidikevmenes deksiotites stelexon anthropinon poron ke epaggelmatikon simvoulon stis epixeiriseis. $O$ emmesos rolos tous stin antimetopisi tis krisis [Self-efficacy beliefs and specialized competencies of human resources executives and career counselors in companies. Their indirect role in the confrontation of the crisis]. Presentation at the 4thPanhellenic Conference of Counseling Psychology (1-4/11). Aristotle University of Thessaloniki, Thessaloniki, Greece.

Karatzogiannis, S., \& Pantazi, S. (2014). Meleti: E eppagelmatiki ekpaidefsi ke katartisi stin Ellada. Adynamies, dynatotites ke prooptikes. [Study:Professional education and training in Greece. Weaknesses, possibilities and prospects]. Small Business Institute - IME-GSEBEE (General Confederation of Professional Craft Traders in Greece). Athens, Greece. 
Mikedaki, K. (2015). E Klimaka epaggelmatikis prosarmostikotitas: Psichometrika xaraktiristika se schesi me tin aftoektimisi fititon [The career adaptabilities scale: Psychometric characteristics and relation to students' self-esteem] (Unpublished MSc thesis). Department of Psychology, Faculty of Philosophy, Pedagogy, and Psychology. National and Kapodistrian University of Athens, Athens, Greece.

Lechner, C. M., \&Tomasik, M. J., \& Silbereisen, R. K. (2016). Preparing for uncertain careers: How youth deal with growing occupational uncertainties before the education-to-work transition. Journal of Vocational Behavior, 95-96, 90-101. Retrieved from https://doi.org/10.1016/j.jvb.2016.08.002.

Malliarou, M., \& Sarafis, P. (2012). Ekonomiki krisi. Tropos epidrasis stin ygeia ton politon ke sta systimata ygeias [Economic crisis: Its impact on citizens' health status and health systems]. Rostrum of Asclepius: Quarterly Scientific online journal of A'Nursing Department, 11 (1), 202-212. Technological Educational Institute of Athens, Athens, Greece.

Paidou, C. (2014). Diiko systima eppagelmatikis ekpaideysis: h germaniki afigisi gia ti syndesi ekpaideysis kai agoras ergasias [Dual vocational education system: The German narrative for linking education to the labor market]. National Institute of Labor and Human Resources.

Rottinghaus, P. J., Buelow, K. L., Matyja, A., \& Schneider M. R. (2012). The career futures inventory-revised: Measuring dimensions of career adaptability. Journal of Career Assessment, 20 (2), 123-139. doi: $10.1177 / 1069072711420849$.

Savickas, M. (1997). Career adaptability: An integrative construct for life-span, life-space theory. The Career Development Quarterly, 45, 247-259.

Savickas, M. (2008). Helping people choose jobs: A history of the guidance profession. In J. A. Athanasou. \& R. Van Esbroeck (Eds.), International handbook of career guidance (pp. 97-113). Dordrecht: Springer Science \& Business Media B.V.

Savickas, M. (2013). Career construction theory and practice. In R. W. Lent \& S. D. Brown. (Eds.), Career development and counseling: Putting theory and research to work (2nd ed., pp. 144-180). Hoboken, NJ: Wiley.

Savickas, M. L., \& Porfeli, E. J. (2012). Career adapt-abilities scale: construction, reliability, and measurement equivalence across 13 countries. Journal of Vocational Behavior, 80 (3), 661-673. Retrieved from http:// dx.doi.org/10.1016/j.jvb.2012.01.011.

Sidiropoulou-Dimakakou, D. (2004). Epaggelmatiki aksiologisi ke symvouleftiki ton ginaikon [Career assessment and counseling of women]. In M. Kassotakis (Ed.), Simvouleftiki ke Epaggelmatikos Prosanatolismos: Theory and Practice [Counseling and career guidance: Theory and practice]. Athens: Typothito-G. Dardanos.

Sidiropoulou-Dimakakou, D., Argyropoulou, K., \& Drosos, N. (2011). Anaptiksi deksiotiton "prosopikis eveliksias ", mia nea prooptiki ston epaggelmatiko prosanatolismo: I draseis tou Kentrou Erevnas ke Aksiologisis stin Epaggelmatiki Symvouleftiki tou Panepistimiou Athinon [Development of "personal flexibility" skills, a new perspective in career guidance: The actions of the career counseling research and assessment center of the University of Athens]. Review of Counseling and Guidance, 94-95, 227-233.

Sidiropoulou-Dimakakou, D., Argyropoulou, K., \& Drosos, N. (2013). Anaptiksi deksiotiton dia viou diaxirisis stadiodromias [Development of lifelong career management skills]. Athens: National Organisation for the Certification of Qualifications and Vocational Guidance (EOPPEP).

Sidiropoulou-Dimakakou, D., Argyropoulou, K., Drosos, N., Kaliris, A., \& Mikedaki, K. (2015). Exploring career management skills in higher education: Perceived self-efficacy in career, career adaptability and career resilience in Greek university students. International Journal of Learning, Teaching and Educational Research, 14 (2), 36-52. Retrieved from http://ijlter.org/index.php/ijlter/issue/view/25.

Sidiropoulou-Dimakakou, D., Argyropoulou, K., Drosos, N., \& Terzaki, M. (2012). Career beliefs of Greek and Non-Greek vocational education students. Creative Education, 3 (7), 1241-1250. doi: 10.4236/ ce.2012.37183.

Sidiropoulou-Dimakakou, D., \& Drosos, N. (2008). Anaptiksi deksiotiton lipsis ekpedeftikon ke epaggelmatikon apofaseon se mathites defterovathmias ekpedefsis: Efarmoges peiramatikou programmatos paremvasis [Development of education and career-related decision-making skills in secondary education students: Implementation of an experimental intervention program]. New Education, 125, 43-59.

Sidiropoulou-Dimakakou, D, Mikedaki, K., Argyropoulou, K, \& Kaliris, A. (submitted for publication). A psychometric analysis of the Greek Career Adapt-Abilities Scale in university students. 
Sidiropoulou-Dimakakou, D., Mylonas, K., \& Argyropoulou, K. (2012, November). Meleti aftoapotelesmatikotitas sto sxediasmo stadiodromias se mia epoxi allagon stin agora ergasias: Mia nea diastash stin epaggelmatiki symvouleftiki [Study of self-efficacy in career planning at a time of change in the labor market: A new dimension in career counseling]. Presentation at the 4th Panhellenic Conference of Counseling Psychology (1-4/11), ELPSE - Sector of Counseling Psychology, Aristotle University of Thessaloniki,Thessaloniki, Greece.

Sidiropoulou-Dimakakou, D., Mylonas, K., \& Argyropoulou, K. (2015). Self-efficacy in career planning: A new approach to career exploration. International Journal of Learning, Teaching and Educational Research, 11 (2), 40-54.

Sidiropoulou-Dimakakou, D., Mylonas, K., Argyropoulou, K., \& Tampouri, S. (2012). Career decision-making difficulties, dysfunctional thinking and generalized self-efficacy of university students in Greece. World Journal of Education, 2 (1), 117-130. doi:10.5430/wje.v2n1p117.

Soresi, S., Nota, L., \& Ferrari, L. (2012). Career adaptabilities scale - Italian Form: Psychometric properties and relationships to breadth of interests, quality of life, and perceived barriers. Journal of Vocational Behavior, 80, 705-711. Retrieved from http://dx.doi.org/10.1016/j.jvb.2012.01.020.

Super, D. E., \& Knasel, E. G. (1981). Career development in adulthood: Some theoretical problems and a possible solution. British Journal of Guidance \& Counselling, 9, 194-201.

Vergas, X (2016). Aftoapotelesmatikotita sto sxediasmo stadiodromias ke lipsi epaggelmatikon apofaseon mathiton triths lykeiou stin Kypro [Self-efficacy in career planning and career decision-making of $12^{\text {th }}$ Grade upper-secondary school students in Cyprus]. (Unpublished MSc thesis). European University of Cyprus, Cyprus.

Zacher, H. (2014a). Career adaptability predicts subjective career success above and beyond personality traits and core self-evaluations. Journal of Vocational Behavior, 84, 21-30. Retrieved from https://doi. org/10.1016/j.jvb.2013.10.002.

Received: November 30, 2017

Accepted: December 26, 2017

Katerina Argyropoulou

$\mathrm{PhD}, \mathrm{M} . \mathrm{Sc}$, Scientific Collaborator of the Laboratory of Career Guidance and Counselling, Department of Philosophy, Pedagogy, and Psychology, University of Athens, Panepistimioupoli-llissia, 15784, Athens, Greece.

E-mail: kargirop@otenet.gr

loanna Tsikoura $\quad$ M.Sc., Educator, European University of Cyprus, Cyprus. E-mail: ioannatsikoura1987@gmail.com

Andronikos Kaliris

Ph.D. Candidate, M.Sc., Scientific Collaborator of the Laboratory of Career Guidance and Counselling, Department of Philosophy, Pedagogy, and Psychology, University of Athens, Panepistimioupoli-llissia, 15784, Athens, Greece.

E-mail: akaliris@ppp.uoa.gr 